\title{
New Beginnings
}

\author{
MATTHEW P. ROMANIELLO
}

$\mathrm{O}$ ur new volume begins with a departure. Tatiana Argounova-Low, following a long term as an associate editor, has left the journal to focus on other projects. We owe her a great debt of thanks for all her work for the journal, which included numerous translations over the years. Most recently, she and Jenanne Ferguson translated the entirety of our last issue on "Indigenous Methodology in the Study of the Native Peoples of Siberia." The project was an enormous undertaking. We know that Tatiana's contributions will continue to be valuable for the field and for Sibirica and wish her the best with her future endeavors.

This issue of Sibirica begins with two articles on the importance of the railroads and its workers to Siberia's development. Alexander Kim and Elena Gnatovskaya's article on the Far Eastern Railway in the 1930s offers an in-depth examination of railroad workers' responses to the political repressions of the decade. The authors' research uncovers a plurality of opinions, registered and recorded by the government, that demonstrate there was no single reaction to the official pronouncements by state authorities. As many, or even more, voices supported colleagues condemned and arrested as those who supported the official process. Olga Povoroznyuk's article on the Baikal-Amur Mainline moves the history of Siberia's railroads in the 1970s and 1980s, and follows through to the post-Soviet era, to reveal the way that workers' memories of this vast Soviet construction project continue to shape attitudes toward the state today. In both articles, the tensions between state authorities and their distant citizens are unpacked as an intrinsic result of shaping policy on the ground, whether resulting from coordination with state decisions or by acting against them.

The next two articles in this issue focus on current anthropology, one through its research and the other from its methodology. Vincent Zvenigorsky and colleagues offer an in-depth analysis of marriage practices in Sakha, comparing the strategies in a rural community, Tolon, and an urban center, Khonuu. Their research reveals the underlying factors that affect the choices to observe or avoid traditional marriage practices. Sviatoslav Shachin's article discusses the recent turn toward 
conceptualizing an Arctic circumpolar civilization and offers solutions for applying this methodology to Siberia.

In the upcoming year we will continue to produce examinations of thematic issues, the latest research, and current field notes, as evidence of the ongoing richness and diversity of the field of Siberian studies. 